\title{
Analisa sistem kerja photovoltaic berdasarkan sudut kemiringan menggunakan monocrystalline dan policrystalline
}

\author{
La Rudawin ${ }^{1}$, Nurlaila Rajabiah², Dwi Irawan ${ }^{3}$ \\ ${ }^{1,2,3}$ Program Studi Teknik Mesin, Universitas Muhammadiyah Metro \\ JI. Ki Hajar Dewantara No. 166 Kota Metro Lampung 34111, Indonesia \\ "Corresponding author: nurlailarajabiah@gmail.com
}

\begin{abstract}
Photovoltaic work systemswere analyzed based on its slope angle using monocrystalline and polycrystalline to the power generated. This research is a direct action research (Action Research) namely the design approach stage, tool fabricating phase, and the tool testing phase. The testing phase conduct measurements and analyses, the stages and process of designing tools, and system testing tools that include measurements of light intensity, temperatur, current, and Voltage. The first year observation data in the form of slope measurements of $0^{\circ}, 30^{\circ}, 60^{\circ}$, that conducted for 15 days at 08:00-16:00 every hour, data, Voltage, temperatur, and light intensity. The results of this study in the form of the maximum acquisition of light intensity received by the solar panel on the slope angle. Solar radiation intensity carried out a great effect on the power $\left(P_{\text {out }}\right)$ of Photovoltaic cell output, wherein the morning solar radiation intensity is greater with the result that it produces greater power. Sunlight intensity in the afternoon and evening tends to decrease so that the power that is halted is smaller. The magnitude of slope angle carried great effect on the output power $\left(P_{\text {out }}\right)$ of Photovoltaic cells, where the greatest power at an angle of $0^{\circ}$ obtained namely maximum $P_{\text {out }} \quad 17.01 \mathrm{~W}$ and maximum Voltage $V_{m}$ is $19.5 \mathrm{~V}$. While the minimum power $P_{\text {out }}$ is $12 \mathrm{~W}$ and minimum Voltage $V_{m} 14 \mathrm{~V}$ which obtained at an angle of $60^{\circ}$. Greatest efficiency ( $\eta$ ) of Photovoltaic cells at an angle of $0^{\circ}$ obtained. This is caused by the Voltage and current output of Photovoltaic cells $V_{m}$ and $I_{m}$ which tend to decrease when the value of the Photovoltaic cell angle is large. Therefore the efficiency of the Photovoltaic cell output will decrease along with the decrease in the Photovoltaic cell output power.
\end{abstract}

Keywords: Photovoltaic, slope angle, power, efficiency.

\section{Abstrak}

Sistem kerja fotovoltaik telah dianalisis berdasarkan sudut kemiringannya menggunakan monocrystalline dan polycrystalline terhadap daya yang dihasilkan. Penelitian ini merupakan penelitian tindakan langsung (Action Research) yaitu tahap pendekatan rancangan, tahap pembuatan alat, dan tahap pengujian alat. Tahap pengujian melakukan pengukuran dan analisis, tahapan-tahapan dan proses perancangan alat serta sistem pengujian alat yang meliputi pengukuran intensitas cahaya, temperatur, serta arus dan tegangan. Data pengamatan tahun pertama berupa pengukuran kemiringan sudut $0^{\circ}, 30^{\circ}, 60^{\circ}$, yang dilaksanakan selama 15 hari pada pukul 08:00-16:00 setiap jam, data-data, tegangan dan Voltase serta temperatur dan intensitas cahaya. Hasil dari penelitian ini berupa perolehan maksimal intensitas cahaya yang diterima oleh panel surya terhadap sudut kemiringan. Intensitas radiasi matahari sangat besar pengaruhnya terhadap daya $\left(\mathrm{P}_{\text {out }}\right)$ keluaran sel fotovoltaik, dimana pada saat pagi hari intensitas radiasi matahari lebih besar sehingga menghasilkan daya yang lebih besar. Sedangkan intensitas cahaya matahari pada siang dan sore hari cenderung menurun sehingga daya yang dihasilkan lebih kecil. Besarnya kemiringan sudut sangat berpengaruh terhadap daya keluaran (Pout) sel fotovoltaik, dimana daya terbesar diperoleh pada sudut $0^{\circ}$ yaitu $\mathrm{P}_{\text {out }}$ maksimum $17.01 \mathrm{~W}$ dan tegangan maksimum $\mathrm{V}_{\mathrm{m}}$ yaitu $19,5 \mathrm{~V}$. Sedangkan daya minimum $\mathrm{P}_{\text {out }}$ yaitu $12 \mathrm{~W}$ dan tegangan minimum $\mathrm{V}_{\mathrm{m}} 14 \mathrm{~V}$ 
yang diperoleh pada sudut $60^{\circ}$. Efisiensi $(\eta)$ sel fotovoltaik terbesar diperoleh pada sudut $0^{\circ}$. Hal tersebut disebabkan oleh tegangan dan arus keluaran sel fotovoltaik $V_{m}$ dan $I_{m}$ yang cenderung akan menurun apabila nilai sudut sel fotovoltaik besar. Sehingga efisiensi keluaran sel fotovltaik akan menurun seiring dengan penurunan daya keluaran sel fotovoltaik.

Kata kunci: Fotovoltaik, sudut kemiringan, daya, efisiensi.

\section{Pendahuluan}

Pada saat ini energi Fosil di dunia semakin menipis, dikarenakan butuh ratusan tahun untuk membentuk fosil dari mahkluk hidup. Pada tahun 2015, berdasarkan World Energy report, Opec Report 2015, cadangan minyak mentah terbukti di dunia (world proven crude oil) berada pada posisi 1.700,1 miliar barel [1].

Dari British petrolium dapat dijelaskan bahwa Negara North America cadangan minyaknya akan habis 30 tahun lagi. Asia Pasific sekitar 15 tahun lagi. Sedangkan yang memiliki cadangan minyak terbanyak adalah amerika selatan dan tengah, akan tetapi kita memiliki kesimpulan, bahwa cadangan minyak dunia pasti akan habis. Oleh sebab itu butuh pengembangan energi alternatif yang lain. Berdasarkan tata letak geografis, Indonesia sangat berpotensi menjadikan energi surya sebagai salah satu sumber energi masa depan, mengingat posisi Indonesia terletak pada garis khatulistiwa. Dalam posisi matahari tegak lurus, sinar matahari yang jatuh di permukaan panel surya di Indonesia seluas satu meter persegi menghasilkan rata rata $4,8 \mathrm{kWh} / \mathrm{m}^{2}$ perharinya [2] .

Akan tetapi fotovoltaik hanya mampu mengubah cahaya matahari menjadi listrik dengan efisiensi puncak antara 9-12\%. Lebih dari $80 \%$ dari radiasi matahari tidak dikonversikan ke energi listrik, melainkan ke energi panas [3]. Bukan Hanya itu, perkembangan fotovoltaik saat ini mendapatkan bahwa fotovoltaik terdiri dari silicon monocristalline dan policristalline dimana masing masing memiliki keunggulan dan kekurangan, serta temperatur pada permukaan fotovoltaik akibat radiasi matahari juga mempengaruhi performa fotovoltaik tersebut. Selain itu perbedaan cara pengolahan silicon pada fotovoltaik dapat mempengaruhi daya yang dihasilkan. Oleh karena itu konsumen pun harus tau manfaat dari silicon monocristalline dan policristalline tersebut sebelum memakainya, serta performa yang terbaik dari fotovoltaik pada sudut kemiringan tertentu.

\section{Tinjauan Pustaka}

\section{Photovoltaic (PVT)}

Pengaruh perubahan arah sudut sel surya menggunakan intensitas cahaya energi matahari terhadap tegangan [4]. Dalam penelitian ini arah sudut yang tepat adalah pada sudut sinar datang matahari terletak pada sudut $125^{\circ}$. Performance PVT menggunakan berbagai macam reflector. Berdasarkan hasil uji coba ekperimental di dapat Efisiensi listrik tahunan rata-rata ditemukan 7,2\%, 7,6\% dan 6,6\% masing-masing. Karena kaca dengan transparansi $92 \%$ digunakan di Perhitungan, penurunan kinerja listrik untuk PVT yang mengkilap dibandingkan Untuk PVT laminasi konvensional adalah persis apa yang diharapkan dari tambahan Kerugian refleksi, yang berarti PVT yang mengkilap menjadi suhu tambahan Efek dibatalkan sepanjang tahun, sedangkan untuk PVT yang tidak berlabel efek suhu positif [3].

Unjuk kerja thermal pelat datar kolektor surya dengan pelat yang dibentuk atau ditekut sesuai bentuk/ roll-bond sesuai bentuk dan ukuran pipa yang digunakan dibandingkan dengan pelat datar yang tidak ditekuk sesuai bentuk pipa. Hasil penelitian menunjukkan efisiensi pelat datar yang dibentuk atau ditekuk sesuai bentuk pipa lebih baik bila 
dibandingkan dengan pelat datar yang tidak ditekuk [5].

\section{Energi surya}

Solar Energy atau panel surya adalah alat untuk mengkonversi panas matahari menjadi energy listrik. Energi solar matahari mulai banyak diteliti dan dikembangkan, selain dikarenakan mulai menipisnya cadangan energi fosil, isu global warming, energy yang dihasilkan juga sangat murah karena energi cahaya matahari. bisa didapatkan secara gratis. Panel surya adalah alat yang dapat merubah energy cahaya matahari menjadi energy listrik. Mereka disebut surya atau "sol" karena matahari adalah sumber cahaya matahari terkuat yang dapat dimanfaatkan. Panel surya sering disebut sel fotovoltaik. Fotovoltaik secara umum dikatakan Panel Solar Cell.

Sel surya (solar cell) adalah suatu bahan semikonduktor yang terdiri dari sebuah wilayah-besar dioda $\mathrm{p}-\mathrm{n}$ junction, di mana, dengan adanya cahaya matahari mampu menciptakan energi listrik. Perubahan ini disebut efek fotovoltaik. adanya energi dari cahaya (foton) pada panjang gelombang tertentu akan mengeksitasi sebagian elektron pada suatu material ke pita energi yang ditemukan oleh Alexandre Edmond Bacquerel (Belgia) pada 1894. Efek ini dapat timbul terutama pada semikonduktor listrik yang memiliki konduktivitas menengah dikarenakan sifat elektron di dalam material yang terpisah dalam pita-pita energi tertentu yang disebut pita konduksi dan pita valensi. Kedua pita energi tersebut berturut-turut dari yang berenergi lebih rendah adalah pita valensi dan pita konduksi, sedangkan keadaan tanpa elektron disebut dengan celah pita (band gap). Dengan alat tersebut cahaya matahari diubah menjadi energy listrik melalui proses aliran-aliran electron positif dan negative didalam cell panel tersebut karena adanya perbedaan muatan. Hasil dari aliran electron akan menjadi listrik searah atau listrik DC yang dapat langsung digunakan untuk mengisi baterai atau aki sesuai dengan tegangan dan arus yang diperlukan.

Proses pengubahan atau konversi cahaya matahari menjadi listrik ini dimungkinkan karena bahan material yang menyusun sel surya berupa semikonduktor. Lebih tepatnya tersusun atas $d u a$ jenis semikonduktor; yakni jenis $n$ dan jenis $p$.

Semikonduktor jenis $n$ merupakan semikonduktor yang memiliki kelebihan elektron, sehingga kelebihan muatan negatif, $(n=$ negatif $)$. Sedangkan semikonduktor jenis $p$ memiliki kelebihan hole, sehingga disebut dengan $p(p=$ positif) karena kelebihan muatan positif. Caranya, dengan menambahkan unsur lain ke dalam semkonduktor, maka kita dapat mengontrol jenis semikonduktor tersebut, sebagaimana diilustrasikan pada Gambar 1.

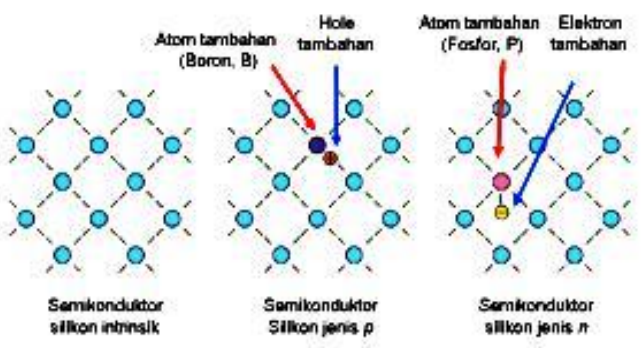

Gambar 1. Semikonduktor jenis $\mathrm{p}$ dan $\mathrm{n}$ yang ditambahkan unsur lain

Pada awalnya, pembuatan dua jenis semikonduktor ini dimaksudkan untuk meningkatkan tingkat konduktifitas atau tingkat kemampuan daya hantar listrik dan panas semikonduktor alami. Di dalam semikonduktor alami (disebut dengan semikonduktor intrinsik) ini, elektron maupun hole memiliki jumlah yang sama. Kelebihan elektron atau hole dapat meningkatkan daya hantar listrik maupun panas dari sebuah semikoduktor.

Pada umumnya, untuk memperkenalkan cara kerja sel surya secara umum, ilustrasi di bawah ini menjelaskan segalanya tentang proses konversi cahaya matahari menjadi energi listrik. 


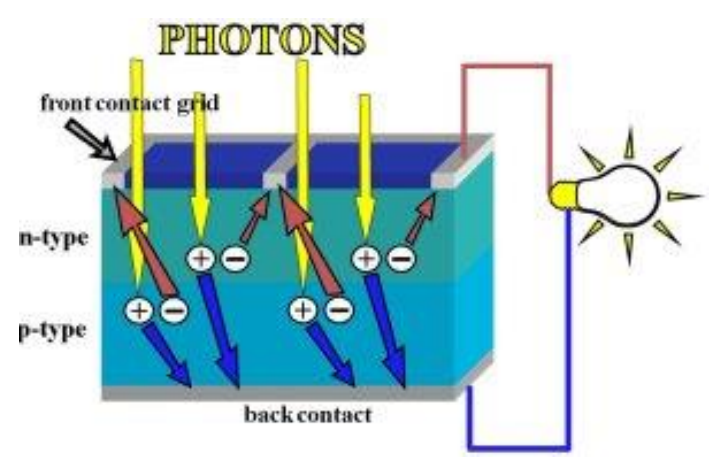

Gambar 2. Kabel dari sambungan semikonduktor dihungkan ke lampu

Pada alat ini solar cell digunakan sebagai sumber energi pengganti listrik untuk mengisi ulang baterai sekunder (charger) yang digunakan untuk menghidupkan portal parkir otomatis.

\section{Daya fotovoltaik}

Daya listrik adalah kemampuan atau kapasitas untuk melakukan suatu usaha atau energI. untuk mengetahui daya yang dihasilkan dari solar cell pada saat pengisian baterai langsung digunakan rumus [6]:

$$
\mathrm{P}=\mathrm{V} \text {. I. }
$$

Keterangan:

$\mathrm{P}$ = daya (dalam Watt, $\mathrm{W}$ )

$\mathrm{V} \quad=\operatorname{ggl}$ (dalam Volt, $\mathrm{V}$ )

$\mathrm{I}=$ arus (dalam Ampere, $\mathrm{A}$ )

4. Efisiensi Penyerapan Daya pada PVT Efisiensi Elektrik PVT di pengaruhi oleh Arus maksimal dan Tegangan maksimal yang di capai dan berbanding terbalik dengan Radiasi dan Luas penampang, hal ini dapat di tuliskan dengan rumus sebagai berikut [6];

$$
\eta=\frac{I m \times V m}{G A_{c}}
$$

5. Pengaruh posisi modul surya terhadap pergerakan arah matahari

Besarnya radiasi yang diterima panel sel surya dipengaruhi oleh sudut datang (angle of incidence) yaitu sudut antara arah sinar datang dengan komponen tegak lurus bidang panel.

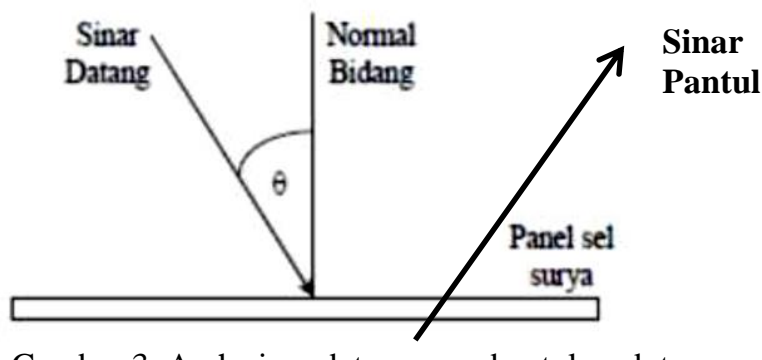

Gambar 3. Arah sinar datang membentuk sudut terhadap normal bidang panel sel surya.

Posisi relatif matahari terhadap modul surya (photovoltaic) di bumi bisa dijelaskan dalam beberapa sudut. antara lain:

1) Latitude (garis lintang)

Adalah sudut lokasi di sebelah utara atau selatan dari equator (khatulistiwa), utara positif; $-900 \leq \varphi \leq 900$. Hal ini pengujian modul surya dilakukan dengan letak geografisnya berada pada $7^{\circ} \mathrm{LS}-110^{\circ} \mathrm{BT}$.

2) Deklinasi $(\delta)$

Adalah sudut posisi matahari terhadap bidang khatulistiwa, utara positif $23,450<\delta<23,450$. Deklinasi dapat diperoleh dengan menggunakan persamaan:

$\delta=23,450 \sin (260), \mathrm{n}=$ hari dalam bulan (1)

3) Kemiringan $(\beta)$

Adalah sudut antara permukaan bidang yang ditanyakan dengan permukaan horisontal. Slope (kemiringan) dapat diperoleh dengan menggunakan persamaan:

$\beta=\operatorname{Tan}-1(\operatorname{Tan} \theta \mathrm{z} \times \cos \gamma \mathrm{s})$

4) Sudut permukaan azimuth $(\gamma)$

Adalah proyeksi kebidang horizontal normal terhadap permukaan dari lokasi bujur, dengan nol menghadap selatan, timur negatif, barat positif ; -

$1800 \leq \gamma \leq 1800$.

5) Sudut jam matahari $(\omega)$

Adalah sudut penyimpangan matahari di sebelah timur atau barat garis bujur lokal karena rotasi pada porosnya sebesar 150 per jam; sebelum jam 12.00 negatif, setelah jam 12.00 positif.

$\omega=(\mathrm{ts}-12) \mathrm{x}$ 
ts $=$ waktu jam (3)

6) Sudut datang $(\theta)$

Adalah sudut antara permukaan radiasi langsung normal vertikal terhadap radiasi langsung vertical kolektor. Sudut datang dapat diperoleh dengan menggunakan persamaan : $\theta=\cos -1(1-\cos 2 \delta \times \sin 2 \omega) 1 / 2 \ldots(5)$

7) Sudut zenith $(\theta z)$

Adalah sudut antara garis vertikal bidang normal dan garis datang sinar matahari.Sudut zenith dapat diperoleh dengan menggunakan persamaan:

$\theta \mathrm{z}=\cos -1(\cos \varphi \times \cos \delta \times \cos \omega+\sin$ $\varphi \times \sin \delta)$

8) Sudut ketinggian matahari ( $\alpha s)$

Adalah sudut antara garis horisontal dengan garis matahari datang pada modul surya (photovolaic).

9) Sudut azimuth matahari $(\gamma s)$

Adalah sudut penyimpangan dari selatan dengan proyeksi radiasi langsung pada bidang horisontal. Penyimpangan ke sebelah timur adalah negatif dan ke sebelah barat adalah positif.

\section{Metode Penelitian}

Penelitian ini dilakukan di Laboratorium Teknik Mesin Universitas Muhammadiyah Metro dan Politeknik Sugar Group. Sedangkan waktu penelitian dilakukan pada rentang waktu pada bulan Mei hingga bulan Agustus 2019. Alat-alat yang digunakan dalam penelitian ini adalah: thermometer, light meter/pyranometer, solar charger control, fotovoltaik, accu. Bahan yang digunakan fotovoltaik dengan nama merk dagang solarland dan memiliki sepesifikasi sebagai berikut:

Maksimum Power $\left(\mathrm{P}_{\max }\right)=20 \mathrm{~W}$

Maksimum Power $\left(\mathrm{V}_{\mathrm{mp}}\right) \quad=18.1 \mathrm{~V}$

Maksimum Power Current $\left(\mathrm{I}_{\mathrm{mp}}\right)=1.12 \mathrm{~A}$

Open Circuit Voltage $\left(\mathrm{V}_{\mathrm{oc}}\right)=22.2 \mathrm{~V}$

Short circuit current $\left(\mathrm{I}_{\mathrm{sc}}\right) \quad=1.2 \mathrm{~A}$

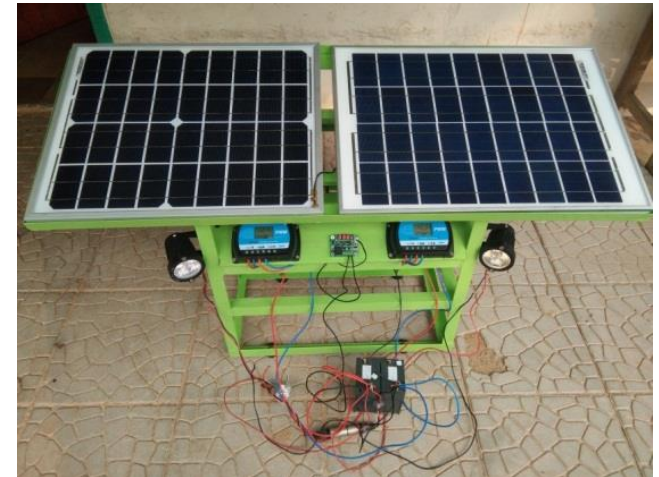

Gambar 4. Photovoltaic monocristaline dan polycristaliner

Tahapan dalam pengujian adalah

1) Pengujian unjuk kerja fotovoltaik pada kondisi sudut tertentu,

2) Persiapan pengujian,

3) Pengukuran temperatur permukaan fotovoltaik di setiap pengujian,

4) Pengukuran arus dan tegangan yang dapat ditangkap oleh fotovoltaik,

5) Pengukuran solar irradiation simulator disetiap pengujian menggunakan solarimeter, dengan waktu pengkondisian sebelum pengujian selama 20 menit,

6) Pengukuran temperatur udara lingkungan.

\section{Hasil dan Pembahasan}

Setelah melakukan pengujian $\mathrm{PV} /$ temperatur lingkungan, intensitas radiasi, serta daya keluaran fotovoltaik di dapatkan hasil sebagai berikut:

Perhitungan daya dan efisiensi fotovoltaik tipe monocristalline pada jam 08.00 WIBdengan sudut $0^{\circ}$. Berdasarkan alat ukur Lux meter di dapat intensitas cahaya matahari jam 08.00 WIBsebesar 687 lux, maka daya dalam Watt (W) sama dengan 0,09290304 kali pencahayaan Ev dalam lux (lx) dikali luas permukaan A dalam satuan meter persegi $\left(\mathrm{m}^{2}\right)$, dibagi dengan efektivitas pancaran $\eta$ dalam satuan lumen per Watt $(\mathrm{lm} / \mathrm{W})$;

$\mathrm{P}(\mathrm{W})=0,09290304 \times \mathrm{Ev}(\mathrm{lx}) \times \mathrm{A}\left(\mathrm{m}^{2}\right) /$ $\mathrm{H}(\mathrm{lm} / \mathrm{W})$

$\mathrm{P}(\mathrm{W})=0,09290304 \times 687(\mathrm{~lx}) \times 1\left(\mathrm{~m}^{2}\right) /$ $1.68(\mathrm{~lm} / \mathrm{W})$

$\mathrm{P}(\mathrm{W})=107.22 \mathrm{Watt}$. 
Pada pukul 08.00 WIB Voltmeter yang terukur 3.80 Volt dan Arus 1A, maka Daya output $=3.80$ Volt $\times 1$ Ampere $=3.8$ Watt. Efisiensi Photovoltaic tipe Monocristaline jam 08.00 wib

$$
\begin{aligned}
& \eta=\text { Pin/P out } \times 100 \% \\
& \eta=(107.22 \text { Watt: } 3.8 \text { Watt }) \times 100 \% \\
& \eta=13 \%
\end{aligned}
$$

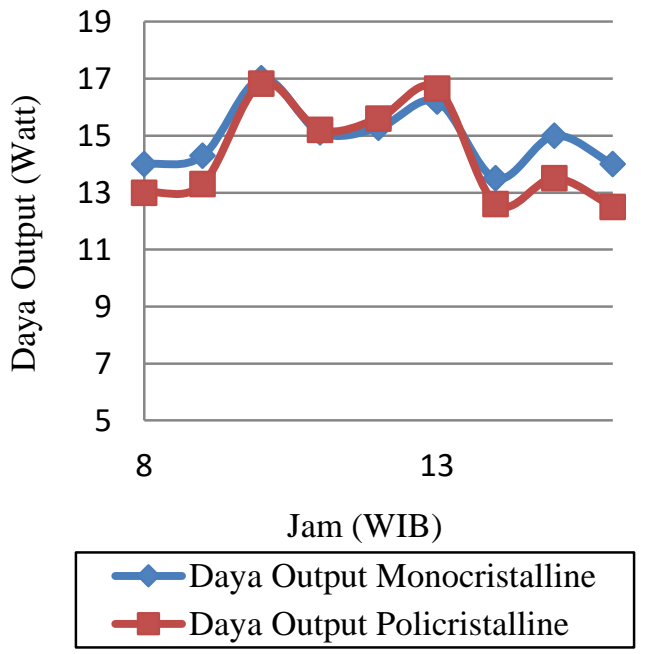

Gambar 5. Daya output PV sudut $0^{\circ}$

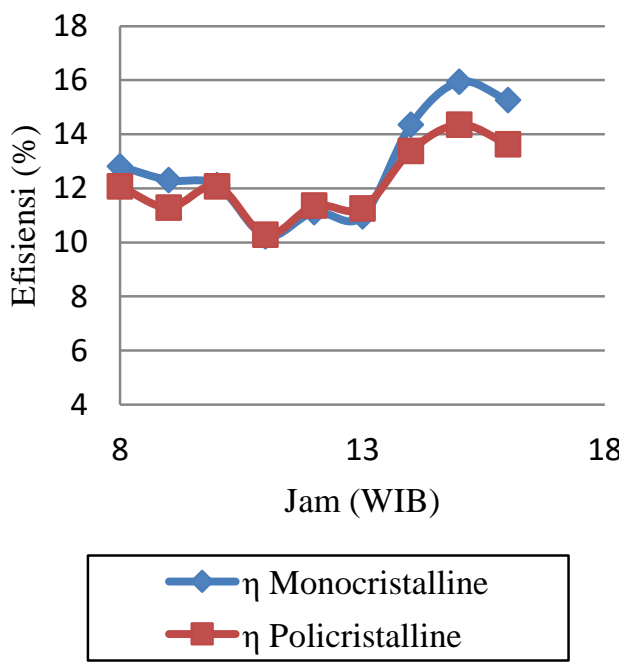

Gambar 6. Efisiesi PV 0º

Dari rata rata hasil pengujian dan pengambilan data sudut kemiringan $0^{\circ}$ pada tanggal 27 sampai 29 September 2019 didapatkan penyerapan maksimum pada pukul 10.00 WIBdan 13.00 WIB, yaitu menghasilkan daya maksimum 18.5 Watt dengan intensitas cahaya 943 lux.

Pada pukul 13.00 WIBterlihat fotovoltaik policristalline memiliki daya serap yang lebih baik dari monocristalline. Akan tetapi kemampuan mempertahankan daya output pada fotovoltaik terlihat pada Gambar 6 efisiensi penyerapan terjadi pada pukul 15.00 WIB dengan sell monocristalline.

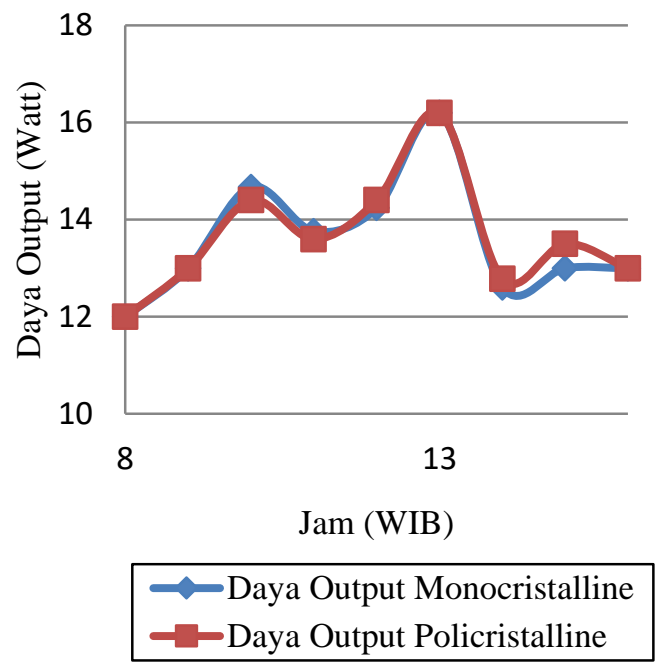

Gambar 7. Daya Output 30 ke arah Barat

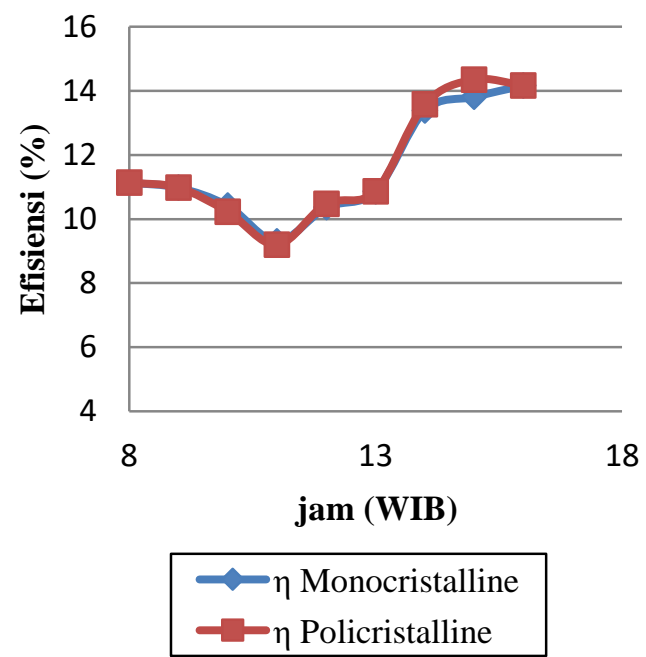

Gambar 8. Efisiensi unjuk kerja PV sudut $30^{\circ} \mathrm{ke}$ arah Barat

Dari hasil rata rata pengujian dan pengambilan data sudut kemiringan $30^{\circ} \mathrm{ke}$ arah barat pada tanggal 30 September 2019 sampai 2 Oktober 2019 didapatkan penyerapan efisiensi maksimum pada pukul 15.00 sampai pukul 16.00 WIB, akan tetapi fotovoltaik menghasilkan daya maksimum 18 Watt dengan intensitas cahaya 878 - 943 lux pada pukul 12 13.00 WIB. Dan perbandingan antara PV 
monocristaline dengan policristaline tidak begitu signifikan.

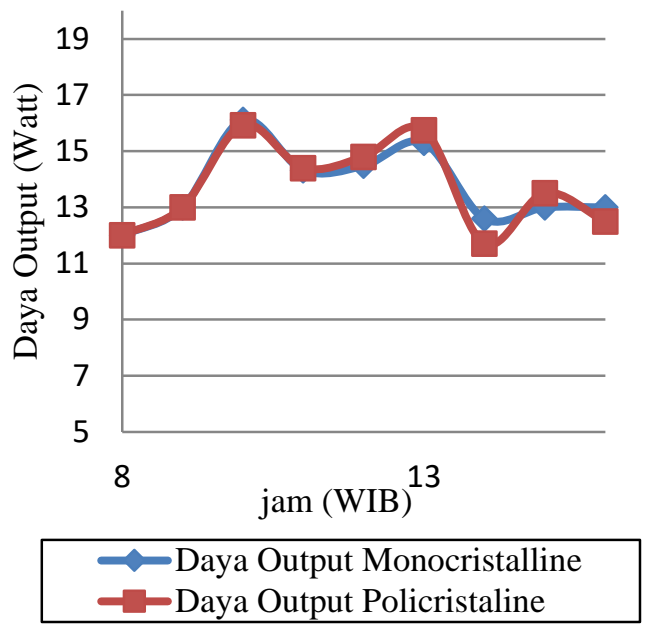

Gambar 9. Daya output $30^{\circ}$ ke arah Timur

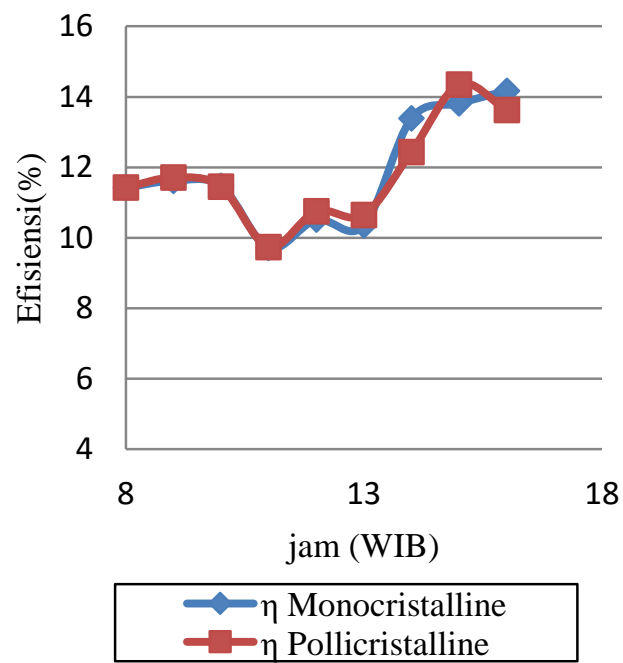

Gambar 10. Efisiensi PV sudut $30^{\circ}$ ke arah Timur

Dari hasil rata rata pengujian dan pengambilan data sudut kemiringan $30^{\circ} \mathrm{ke}$ arah timur pada tanggal 3 sampai 5 Oktober 2019, didapatkan Efisiensi penyerapan maksimum pada pukul 15.00 sampai pukul 16.00 WIB, yaitu 14\% akan tetapi daya maksimum didapat pada pukul 10.00 WIB yaitu menghasilkan 16.2 Watt dengan intensitas cahaya 878 - 943 lux. Dan perbandingan antara PV Monocristaline dengan policristaline tidak begitu signifikan, perbedaan penyerapan daya saat lux rendah lebih setabil oleh monocristaline dan policrystaline dapat menyerap daya input maksimal saat jam 11.00 WIB sampai 13.00 WIB.

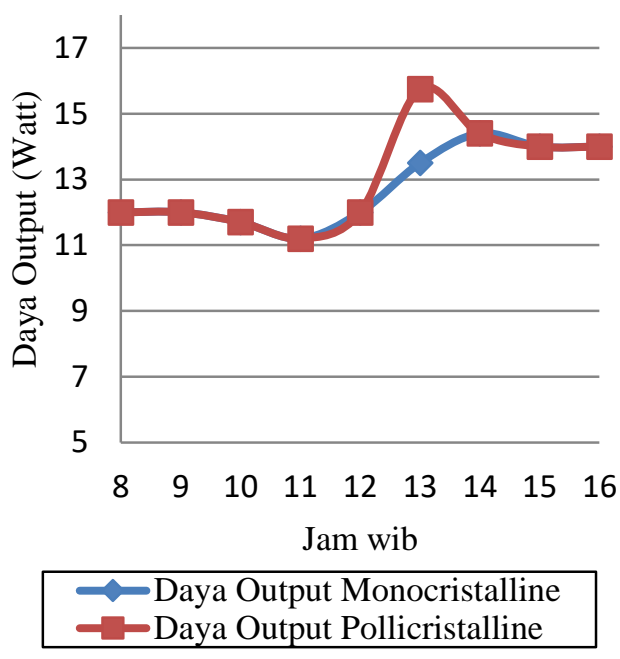

Gambar 11. Daya Output $60^{\circ} \mathrm{ke}$ arah Barat

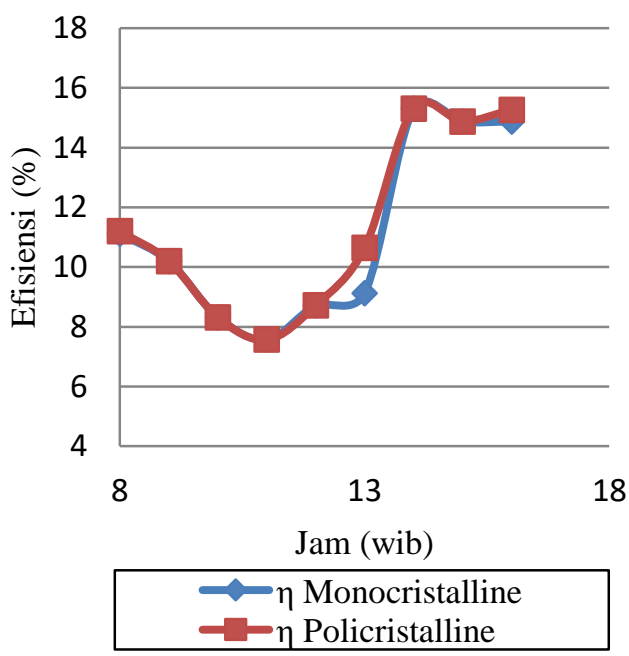

Gambar 12. Efisiensi PV sudut $60^{\circ}$ ke arah Barat

Dari hasil rata rata pengujian dan pengambilan data sudut kemiringan $60^{\circ} \mathrm{ke}$ arah barat pada tanggal 6 sampai 8 Oktober 2019, didapatkan penyerapan maksimum pada pukul 13.00 sampai pukul 14.00 WIB, yaitu menghasilkan daya maksimum 17.5 Watt dengan intensitas cahaya 878 - 943 lux. Serta efisiensi penyerapan Daya pada pukul 14.00 WIB mencapai 15\%. Dan perbandingan antara PV monocristaline dengan policristaline terlihat pada jam 13.00 WIB. 


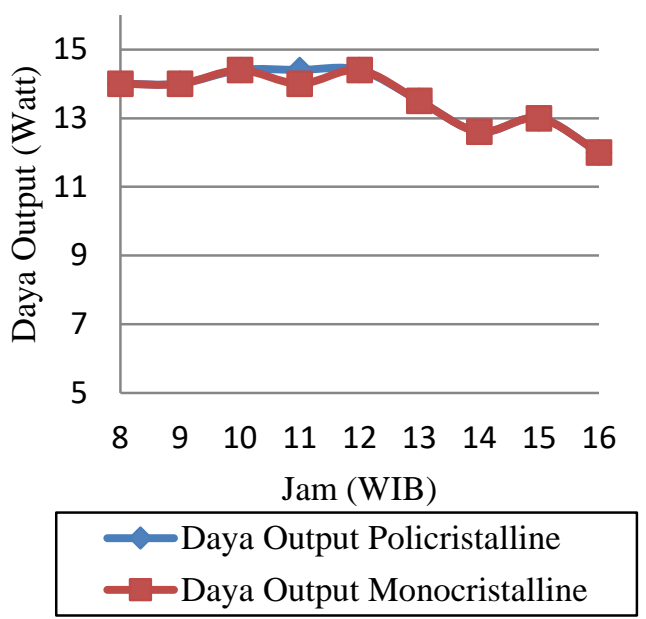

Gambar 13. Daya output $60^{\circ}$ ke arah Timur

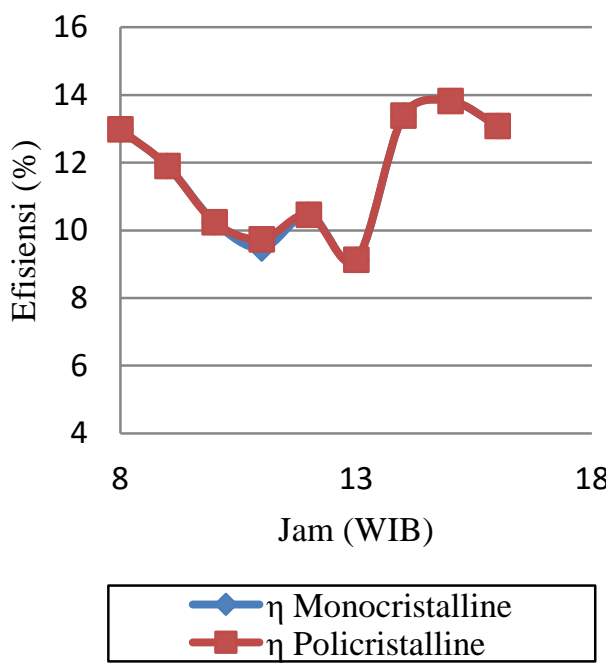

Gambar 14. Efisiensi PV 60 ke arah Timur

Dari hasil rata rata pengujian dan pengambilan data sudut kemiringan $60^{\circ} \mathrm{ke}$ arah barat pada tanggal 6 sampai 8 Oktober 2019, didapatkan penyerapan maksimum pada pukul 13.00 sampai pukul 14.00 WIB, yaitu menghasilkan daya maksimum 17.5 Watt dengan intensitas cahaya 878 - 943 lux. Dan perbandingan antara PV Monocristaline dengan policristaline tidak begitu signifikan.

Efisiensi terbaik terdapat pada fotovoltaik sudut $0^{\circ}$ pukul 15.00 WIB dengan efisiensi mencapai $16 \%$ dan Daya output tertinggi pada pukul 10.00 WIB. Hal ini dapat dilihat pada Gambar 15.

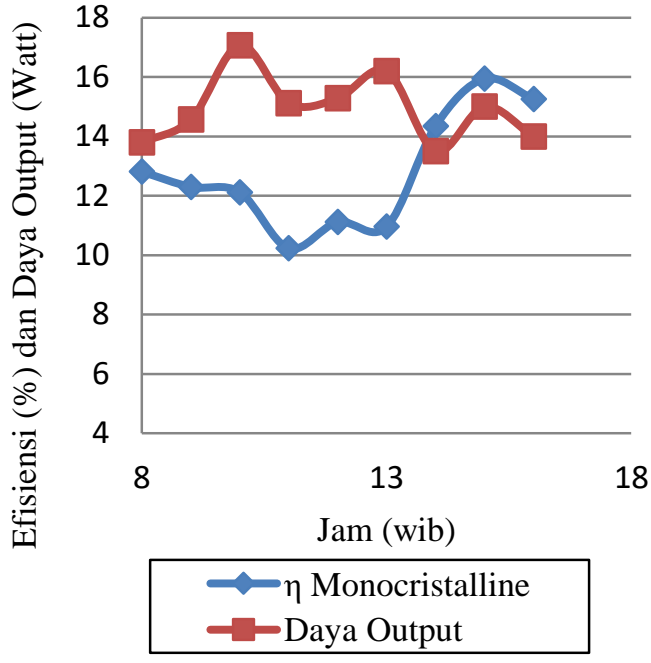

Gambar 15. Perbandingan daya output, efisiensi (\%), Jam (WIB)

\section{Kesimpulan}

Intensitas radiasi matahari sangat besar pengaruhnya terhadap daya $\left(\mathrm{P}_{\text {out }}\right)$ keluaran sel fotovoltaik, dimana pada saat intensitas radiasi matahari (E) pukul 09.00 WIB yaitu $898 \mathrm{~W} / \mathrm{m}^{2}$ diperoleh daya ( $\mathrm{P}_{\text {out }}$ ) 17.01 Watt. Sedangkan pada pukul 12.00 WIBintensitas radiasi matahari sebesar 876 $\mathrm{W} / \mathrm{m}^{2}$ diperoleh daya $\left(\mathrm{P}_{\text {out }}\right)$ yaitu 15.6 Watt dan kembali menurun pada pukul 16.00 WIB $585 \mathrm{~W} / \mathrm{m}^{2}$ dengan daya $\left(\mathrm{P}_{\text {out }}\right.$ ) sebesar 14 Watt.

Besarnya kemiringan sudut sangat berpengaruh terhadap daya keluaran $\left(\mathrm{P}_{\text {out }}\right)$ sel fotovoltaik, dimana daya terbesar diperoleh pada sudut $0^{\circ}$ yaitu $\mathrm{P}_{\text {out }}$ maksimum $17.01 \mathrm{~W}$ dan tegangan maksimum $\mathrm{V}_{\mathrm{m}}$ yaitu $19,5 \mathrm{~V}$, arus maksimum $\mathrm{I}_{\mathrm{m}} 1$ A dan Short Circuit Current $\left(\mathrm{I}_{\mathrm{sc}}\right)$ 1,45 A, Open Circuit Voltage $\left(\mathrm{V}_{\mathrm{oc}}\right) 20,60 \mathrm{~V}$, fill factor $(F F)$ 0,65. Sedangkan daya minimum $\mathrm{P}_{\text {out }}$ yaitu $12 \mathrm{~W}$ dan tegangan minimum $\mathrm{V}_{\mathrm{m}} 14 \mathrm{~V}$ dengan arus minimum Im 0,8 A, Short Circuit Current $\left(\mathrm{I}_{\mathrm{sc}}\right)$ 1,07 A, Open Circuit Voltage $\left(\mathrm{V}_{\text {oc }}\right) 20,10 \mathrm{~V}$, fill factor $(F F)$ 0,70 yang diperoleh pada sudut $60^{\circ}$.

Efisiensi ( $\eta$ ) sel fotovoltaik terbesar diperoleh pada sudut $0^{\circ}$. Hal tersebut disebabkan oleh tegangan dan arus keluaran sel fotovoltaik $V_{m}$ dan $I_{m}$ yang cenderung akan menurun apabila nilai 
sudut sel fotovoltaik besar. Sehingga efisiensi keluaran sel fotovltaik akan menurun seiring dengan penurunan daya keluaran sel fotovoltaik. Dari hasil perhitungan diperoleh efisiensi ( $\eta$ ) maksimum yaitu $16 \%$ yang terjadi pada sudut $0^{\circ}$, sedangkan efisiensi minimum yaitu $7.57 \%$ yang terjadi pada sudut $60^{\circ}$ ke arah Timur.

\section{Referensi}

[1]. Allan. James, D. Zahir. S.Siniska dan Mauricette. L., 2015. Performance Testing of Thermal and Photovoltaic Thermal Solar Collectors, Inggris: School of Engineering and Design, Brunel University

[2]. Kementrian Energi dan Sumber Daya Mineral "Strategi Pengolahan Energi Nasional dalam Menjamin keamanan ketersidiaan Energi,", 2010

[3]. Zondag, H. A., 2008, Flat-plat PVThermal collectors and systems: A Review, Renewable and sustainable Energy Reviews Journal, vol 12, 891-959.

[4]. Bahari, S., Laka, A., Rosmiati, 2017, Pengaruh Perubahan Arah Sudut Sel Surya Menggunakan Energi Matahari Intensitas Cahaya terhadap Tegangan, SemNasTek 2017, journal UMJ, e-ISSN: 2460-8416

[5]. Davide. Del Col, Andrea Padovan, Matteo Bortolato, 2013, Thermal Performance of Flat Solar Collector with Sheet-Tube and Roll Bond Absorbers, Canada: Elsevier Ltd.

[6]. Susandi, A., I. Herlianti, M. Tamamadin, \& Nurlela, I. 2008. Dampak perubahan iklim terhadap ketinggian muka laut di wilayah Banjarmasin. Jurnal Ekonomi Lingkungan 12(2). 